\title{
Grape Growing and Processing in Brazil
}

\author{
U.A. Camargo, J.F.S. Protas and L.M.R. Mello \\ Embrapa \\ National Research Center for Grape and Wine \\ Bento Gonçalves, RS \\ Brazil
}

Keywords: tropical viticulture, wine grape, juice grape, table grape, climate for grapes

\begin{abstract}
Grape growing was introduced in Brazil during the colonial period, in the $16^{\text {th }}$ century and has become a commercial activity in the temperate climate regions in the south of the country only in the $20^{\text {th }}$ century. Grapes of American origin, especially Vitis labrusca and Vitis bourquina cultivars used to be predominant. Tropical viticulture has started in the $1960 \mathrm{~s}$, when fine table grapes of the cultivar 'Italia' were grown in the Submédio São Francisco Valley in northeast Brazil. It has spread to other regions in the following decades. Important technological advancements have been achieved with the refinement of the plant management techniques and the development of rootstocks and cultivars for table grapes, for wine and juices which are adapted to tropical climates. In this article, the main grape growing regions of Brazil are presented. It contains information on the cultivars used, the technology of production, the products and the markets to which they are destined.
\end{abstract}

\section{INTRODUCTION}

Grape growing was initiated in Brazil in the $16^{\text {th }}$ century by the Portuguese settlers. Practiced as a domestic culture until the end of the $19^{\text {th }}$ century, it has become a commercial activity since the beginning of the $20^{\text {th }}$ century through the initiative of Italian immigrants, who settled in the south of the country from 1875 on.

Vines of American origin, mainly Vitis labrusca cultivars build the basis for the development of the Brazilian viticulture. Outstanding were the cultivars 'Isabel' as a grape for winemaking and 'Niagara Branca' and 'Niagara Rosada' as table grapes. 'Jacquez' and 'Herbemont', both Vitis bourquina cultivars and the interspecific hybrid 'Seibel 2' were important cultivars for the Brazilian viticulture of that time, among other less relevant ones. Despite the endeavors to cultivate the European cultivars (Vitis vinifera), these were not significant in the early commercial viticulture in Brazil, due to the losses caused by fungal diseases, especially by downy mildew (Plasmopara viticola) and anthracnosis (Elsinoe ampelina). Since the middle of the $20^{\text {th }}$ century, when synthetic fungicides have become available for effective control of these diseases, the European grapevine cultivars have gained more importance for grape growing in the state of Rio Grande do Sul and with the spread of the 'Itália' grape, especially in the state of São Paulo.

Since its beginning until the 1960s, Brazilian viticulture was restricted to the southern and southeastern regions, featuring the cultural traits of the temperate climate with an annual vegetative cycle and a dormancy period, defined by low temperatures during the winter months. Since the decade of 1960, the 'Itália' grape has been successfully grown in the semiarid region the Submédio São Francisco Valley, which represented the beginning of the tropical viticulture in Brazil. Based upon this cultivar, tropical grape growing expanded quickly with the consolidation of grapevine belts in Northern Paraná in the 70s and in the Northwest of São Paulo and Northern Minas Gerais in the following decade. From 1990 on, several new grape-growing belts emerged, some of them for growing table grapes, others with the objective of producing grapes for wine and juice.

This article shows the features of the Brazilian viticulture and describes both, the 
regions which traditionally produce grapes and the emerging grape growing areas in Brazil.

\section{THE GENERAL SCENARIO OF THE BRAZILIAN VITICULTURE}

In Brazil, grapes are grown on approximately 71,000 hectares; there are vineyards from the very south of the country, at a latitude of $30^{\circ} 56^{\prime} 15^{\prime \prime} \mathrm{S}$, to regions located near the equator, at a latitude of $5^{\circ} 11^{\prime} 15^{\prime \prime} \mathrm{S}$. Depending on the environmental diversity, there are grapevine belts that display characteristics of temperate regions, with a dormancy period; in the subtropical belts, the vines are grown in two annual cycles, which are defined by a period with low temperatures, with frost risk. On the other hand, there are the tropical grapevine belts, where it is possible to carry out successive pruning and to achieve two and a half to three vegetative cycles per year. One and a half million tons of grapes are produced per year.

Around $45 \%$ of the Brazilian grape production is processed into wines, juices and other derivatives and $55 \%$ is commercialized as table grapes. Of all industrialized products, $60 \%$ are popular table wines and $21 \%$ are table juices, both processed out of grapes of American origin, especially of the cultivars $V$. labrusca, $V$. bourquina and different interspecific hybrids. Around $10 \%$ are fine wines, processed from $V$. vinifera cultivars. The remaining $9 \%$ of industrialized products consists of other derivatives of grapes and wine. A great part of the Brazilian production of grapes and their derivatives are destined to domestic consumption. The main product for exportation, with regard to volume, is grape juice. Thirty percent of the total production is destined to the external market, only $5 \%$ of the table grape production being exported. Less than $1 \%$ of the wine production is commercialized abroad.

\section{MAIN GRAPE PRODUCING REGIONS}

Grape growing is already an established activity in nine Brazilian regions. Outstanding as grape growing zones of temperate climate are the regions of the Southern Frontier and of the Serra Gaúcha in the state of Rio Grande do Sul; the region of the Rio do Peixe Valley, Santa Catarina state; the southeastern region of the state of São Paulo and the southern part of Minas Gerais state. Northeastern Paraná is typically subtropical. The northwest of the state of São Paulo, the north of the state of Minas Gerais and the Submédio São Francisco Valley are tropical zones, where the management systems are adapted to the specific environmental conditions. Besides these, new grape growing regions are emerging in different places in Brazil, be it under temperate conditions or be it in hot climates.

In the colder regions, the viticultural practices are the same as those practiced in traditional grape growing countries, whereas in hot climate regions, the management techniques are adapted to each specific situation. The vegetative and production cycles are defined according to climatic conditions and market opportunities. Under subtropical and tropical conditions specific techniques are applied for the induction of bud burst. Problems caused by apical dominance, as well as the induction of inflorescence ontogenesis in cultivars with adaptation problems, the control of the vegetative vigour and the phytosanitary management require specific techniques.

The main plant disease problems are alike in climates, the temperate and the hotter ones, among which downy mildew (Plasmopara viticola) is the most aggressive in all regions. Other important fungi diseases are powdery mildew (Uncinula necator) in hot regions and anthracnosis (Elsinoe ampelina) in temperate zones.

In the following are presented Brazil's regions with viticulture tradition as well as its main emerging grape growing belts. The regions are dealt with in groups according to their environmental characteristics: temperate, subtropical and tropical viticulture.

\section{VITICULTURE IN A TEMPERATE CLIMATE}

It has traditional features and is concentrated in the southern and southeastern states. It represents around $88 \%$ of the area planted with vineyards and more than $98 \%$ of 
the grapes cultivated for processing (wines, juices and other derivatives) of the country. Several management systems are employed, depending on the region and the type of product. Mostly, conventional cultivars and rootstocks are used, which have been introduced from other countries. The use of some new cultivars developed in Brazil is now expanding.

\section{The Southern Frontier of Rio Grande do Sul}

This region features open land with an undulating topography, appropriate for mechanical cultivation techniques. It is situated at $30^{\circ} \mathrm{S}$ and $55^{\circ} \mathrm{W}$, at an altitude between $75 \mathrm{~m}$ and $220 \mathrm{~m}$. The mean temperature lies around $19,5^{\circ} \mathrm{C}$ and average rainfalls amount to approximately $1,400 \mathrm{~mm}$, while the relative air humidity is about $75 \%$. The climatic diversity allows for the production of wines with characteristics of "typicality" within the same region, depending on the specific environmental conditions of each production site. The Southern Frontier Region, currently with 1,000 hectares planted to grapevines, has become consolidated as producer region of fine wines since the decade of 1980. Among the exclusively grown Vitis vinifera cultivars, prevail the red grapes 'Cabernet Sauvignon', 'Merlot', 'Tannat', 'Cabernet Franc' and 'Pinot Noir', while 'Chardonnay', 'Sauvignon Blanc' and 'Ugni Blanc' ('Trebbiano') predominate among the white grapes grown here. 'SO4' is the commonly used rootstock in the region. The vineyard is conducted in vertical trellis, spaced at 3,5 $\mathrm{m} \times 1,5$ to $2,0 \mathrm{~m}$ and the vines are spur-pruned or cane-pruned (Guyot). The vegetative period begins in September, pruning is carried out in August and the harvest occurs in January and February. The vineyards in the region produce between 8 and $12 \mathrm{t} / \mathrm{ha}$, depending on the cultivar and the crop. Mainly calm wines are produced, which are destined to the domestic market.

\section{Serra Gaúcha}

The Serra Gaúcha is situated in the Northeast of Rio Grande do Sul state. Its geographical coordinates and mean climatic indicators are: latitude $29^{\circ} \mathrm{S}$, longitude $51^{\circ}$ $\mathrm{W}$, altitude $600-800 \mathrm{~m}$, rainfall $1,700 \mathrm{~mm}$, temperature $17,2^{\circ} \mathrm{C}$ and relative air humidity $76 \%$. It is the major grape growing region of the country, with approximately 32,000 hectares covered with vineyards. Viticulture in this area is carried out on small holdings, predominantly using family labor; the degree of mechanization is low due to the regions topographical relief. Pruning is accomplished in July-August and the harvest is concentrated in January-February. More than $80 \%$ of the production consists of American grapes ( $V$. labrusca, $V$. bourquina) and interspecific hybrids, among which 'Isabel', 'Ives', 'Niagara Branca', 'Concord', 'Niagara Rosada', 'Jacquez' and 'Seibel 1077' prevail. In regards to the $V$. vinifera grapes (5,376 hectares), the white grape cultivars 'Moscato Branco', 'Riesling Italico', 'Chardonnay' and 'Trebbiano' ('Ugni Blanc') are predominant. The main red grape cultivars are: 'Cabernet Sauvignon', 'Merlot', 'Cabernet Franc', 'Tannat', 'Ancellota' and 'Pinotage'. Among the more than 10 rootstocks used, 'Solferino' (local selection of berlandieri $\times$ riparia) and '1103 Paulsen' are the most commonly used. The plant density lies between 1,600 and 3,300 plants/hectare and the predominant training system is the arbor or pergola (horizontal), which yields 10 to $30 \mathrm{t} / \mathrm{ha}$, depending on the cultivar and the crop. The major part of the grape harvest is channeled to processing into wines, juices and other derivatives. The grapes of American origin are mainly used for making juice and table wines, products which are very well accepted on the domestic market because of the typical taste and aroma of labrusca grapes. With respect to fine wines, the production of high quality sparkling wines is worth mentioning, besides the calm white and red wines. This region, which holds a highly developed wine making technology, has been growing as producer of quality wines with the indication of geographical origin (Tonietto, 2005). A small percentage of the grape production, especially of American grapes, such as 'Niagara Rosada' and 'Isabel', is channeled into the fresh market as table grapes. 


\section{Rio do Peixe River Valley}

Situated in Santa Catarina state, at latitude $27^{\circ} \mathrm{S}$, longitude $51^{\circ} \mathrm{W}$, altitude 600 $800 \mathrm{~m}$, this region presents the following average climatic indicators: $1,800 \mathrm{~mm}$ annual rainfall, $17,1^{\circ} \mathrm{C}$ temperature, $80 \%$ relative air humidity. The area planted to grapevines covers approximately 1,800 hectares and is very similar to the Serra Gaúcha as far as the agrarian structure, the topography and the type of viticultural exploitation, which is based on family labor, is concerned. The major part of the grape production is destined to industrial processing into wines and juices. The cultivar 'Isabel' is grown on approximately $75 \%$ the vineyard area, followed by other $V$. labrusca cultivars and interspecific hybrid cultivars, such as 'Niagara Branca', 'Niagara Rosada', 'Ives' and 'Couderc 13'. The production of vinifera grapes amounts to less than $5 \%$ of the produced grapes. The prevailing training system is the arbor or pergola (horizontal) and the plant density lies between 1,600 and 3,000 plants/ha. The region stands out for the production of table wines made of labrusca grapes for the domestic market. The production of concentrated grape juice has been increasing, with good perspectives of significant expansion on the exportation market.

\section{Eastern São Paulo}

Situated at $23^{\circ} \mathrm{S}, 47^{\circ} \mathrm{W}$ and between 700 and $900 \mathrm{~m}$ altitude, the region of Eastern São Paulo receives $1,400 \mathrm{~mm}$ annual rainfalls, presents temperatures of $19,5^{\circ} \mathrm{C}$ and relative air humidity of $70,6 \%$. This region, where the altitude counterbalances the latitude, possesses conditions for grape growing practices of the temperate climate. The winter is mild, however, subject to the occurrence of frost and the incidence of rainfall is low. The summer is hot and rainy, thus propitious to the incidence of fungal diseases such as downy mildew and bunch rot, among others. The total area planted with vineyards is about 8,000 hectares, and viticultural production can be divided into three categories: in the first group, representing around $68 \%$ of the planted area, consists of the American table grapes, mainly 'Niagara Rosada'. The vines are conducted in vertical trellis and spur-pruned, at a density of approximately 4000 plants/hectare and grafted on rootstocks ' $106-8 \mathrm{Mgt}$ ' or 'IAC 766'. The average yield with this system is about 8-10 t/hectare. The harvest is concentrated in December-January. The second group contains the grapes for wine, representing approximately $4 \%$ of the total volume. All grapes are American or hybrids cultivars, among which 'Seibel 2' holds an outstanding position. In general, the vines are grafted on the rootstocks '106-8 Mgt' or 'IAC 766' and in some areas grown on their own roots. The most commonly employed training system is the simple espalier system. The third group consists of the European table grapes, the cultivar 'Italia' and its mutations 'Rubi' and 'Benitaka', representing nearly $28 \%$ of the total grapevine growing area of this region. The vineyards are trained in the arbor or pergola system (horizontal), with 330 to 625 plants/hectare and grafted on the rootstocks ' $420^{\mathrm{A}}$, or 'IAC 766 '. The harvest occurs in February and March, yielding about 30 t/ha.

\section{Southern Minas Gerais}

This grapevine belt is situated at $21^{\circ} \mathrm{S}, 40^{\circ} \mathrm{W}$, at an altitude of $1150 \mathrm{~m}$. The climate of the region is characterized by average rainfalls of $1500 \mathrm{~mm}$, mean annual temperatures of $19^{\circ} \mathrm{C}$ and $75 \%$ relative air humidity. On an area smaller than 300 ha, there are traditionally grown American grapes ( $V$. labrusca and $V$. bourquina). The main cultivars used are 'Jacquez', 'Ives', 'Niagara Rosada' and 'Niagara Branca'. As the latitude is counterbalanced by the altitude, the type of viticulture practiced here has the characteristics of that of temperate climates, with pruning in July and August and harvest in December and January. The major part of the vines is grown on their own roots and trained in vertical trellis system. Most of the grape production is processed into wine for regional consumption; however, in the case of the 'Niagara' grapes, a part of the production is consumed as fresh fruit. 


\section{The Emerging Grapevine Belts}

The grape growing belt of São Joaquim is situated at $28^{\circ} \mathrm{S}$ and $49^{\circ} \mathrm{W}$, at an altitude between $950 \mathrm{~m}$ and $1,400 \mathrm{~m}$. In this belt exclusively $V$. vinifera cultivars are grown for the production of fine wines, especially red wines. In this region, vineyards have been established since 2001. In 2005, the area planted with grapevines reached 180 hectares. 'Cabernet Sauvignon', grown on around 90\% of the area, is the main cultivar planted in the region, followed by 'Merlot' with 7\%, while the remaining 3\% are occupied by the cultivars 'Pinot Noir', 'Chardonnay', 'Cabernet Franc', 'Malbec' and 'Sauvignon Blanc'. The viticultural activity aims at the production of high quality fine wines in modern industrial facilities which have been established recently or which are currently being established.

\section{SUBTROPICAL VITICULTURE}

Viticulture with subtropical characteristics has been developed in northern Paraná where, predominantly, table grapes are grown. The region plays an important role in the domestic supply of table grapes for fresh consumption. It is located at latitude $23^{\circ} \mathrm{S}$, longitude $51^{\circ} \mathrm{W}$ and an altitude of 250 through $800 \mathrm{~m}$. The climate is typically subtropical, featuring the following average climate indicators: rainfalls of $1,600 \mathrm{~mm}$, average annual temperature $20,7^{\circ} \mathrm{C}$ and $73 \%$ relative air humidity. The average temperature during the colder months (June and July) is around $16,7^{\circ} \mathrm{C}$ with risk of frost incidence in this period. The rainfalls are concentrated in the period between October and April. Between May and September, the average rainfall lies below $100 \mathrm{~mm}$ per month, which makes irrigation necessary. Small holdings with the use of family labor are predominant. The main product of the region is fine table grapes, especially the cultivar 'Italia' and its colored mutations 'Rubi', 'Benitak' and 'Brasil'. Occupying an area of approximately 3,300 hectares, the vineyards are trained in the trellis or arbor system (horizontal), the density is 400 to 800 plants/ha. On second position with regard to the importance, comes the production of labrusca table grapes. On an area of about 700 ha, 'Niagara Rosada' vines are trained in the vertical trellis system with high density planted vines (4,000 plants/ha). The most used rootstocks are ' 420 A' and 'IAC 766 '. Generally, there are three crops in two years, and the pruning is carried out in June-July and in January-February. In this system, it is necessary to treat the plants in order to induce a uniform bud burst. Harvest occurs in December-January and in April-May, respectively. Besides the production of table grapes, nearly 350 ha labrusca grapes have been established with the objective of producing concentrated juice as part of a project aiming at planting 1,000 ha with grapevines until 2008. In the case of grapes for juice, the intention is to carry out just one harvest per year in the period of January through March, in order to make use of industrial orange juice facilities which are idle in this time of the year.

\section{TROPICAL VITICULTURE}

Although planting grapevines in tropical climates has begun only relatively recently, it has already reached significant technological evolution. After having initially produced only 'Italia' grapes, practically the only grown variety up to the 1990s, the tropical grapevine growing has begun the 21st century with technology to produce seedless grapes, increasing the table grapes exportations; with technology to produce $V$. labrusca 'Niagara Rosada' which, before, had been restricted to the south of the country; with technology for the production of fine grapes $(V$. vinifera) for high quality wines; and the production of high quality $V$. labrusca grapes, appropriate for juice production in tropical regions have become available as well. These technological packages consist of new cultivars and rootstocks, developed especially for these climates and of well adjusted management techniques which made it possible to consolidate the regions described below and point out a strong tendency towards the emerging of new grape growing belts in the tropical regions of Brazil. 


\section{Northwestern São Paulo}

This region is situated at $20^{\circ} \mathrm{S}, 50^{\circ} \mathrm{W}$ and at an altitude between 450 and $550 \mathrm{~m}$. The climate is characterized by a rainy season between November and April and a dry season between May and October; therefore, irrigation is indispensable. The average rainfall per year lies around $1,300 \mathrm{~mm}$ and the mean annual temperature is $22,3^{\circ} \mathrm{C}$. The temperatures are high throughout the year, thus the low risk of frost incidence and the feasibility of successive vegetative cycles. According to the distribution of rainfalls, pruning is carried out twice a year, one for the production between March and June and the other one for the plant formation between October and December. Consequently, the harvest period extends from August to November. Due to the low incidence of rainfall in August and September, this period is favorable for the production of high quality grapes. On a vineyard area of approximately 900 ha, table grapes are absolutely prevalent. Among the fine grapes ( $V$. vinifera), 'Italia' is the main cultivar followed by its mutations 'Rubi' and 'Benitaka'. 'Niagara Rosada' ( $V$. labrusca), until then not present on the regional vineyards, has been grown from the year 2000 on. 'IAC 572' is the most used rootstock and on less expressive positions are 'IAC 313' and ' $420 \mathrm{~A}$ '. The training system is the arbor or pergola (horizontal) and the productivity of the vineyards lies between 25 and $40 \mathrm{t} / \mathrm{ha}$. Grape growing is performed on small holdings, using family labor complemented by partnerships paid by percentual participation in the production revenues. The production is absorbed by the domestic market.

\section{Northern Minas Gerais}

This producer belt is situated on the banks of the São Francisco River at $17^{\circ} \mathrm{S}, 44^{\circ}$

$\mathrm{W}$ and an average altitude of $470 \mathrm{~m}$. The mean annual rainfall is approximately $1050 \mathrm{~mm}$, concentrate between November and April and the mean annual temperature is $23^{\circ} \mathrm{C}$. The production of the nearly 500 ha large vineyard area is totally absorbed by fresh consumption. The production is still based on the 'Italia' grape and its mutations 'Rubi', 'Brasil' and 'Benitaka'; however, the cultivation of 'Niagara Rosada' and the seedless grape cultivars, especially Brazilian cultivars, have been increased. The tropical rootstocks 'IAC 313', 'IAC 572' and 'IAC 766' are the mainly used. The vineyards are trained in the arbor or pergola system (horizontal) with two vegetative cycles and one harvest/year carried out in the period from July through October, taking advantage of the dry period extending between May and October. A large part of the production is destined to the supply of the Brazilian market; however, some smaller amounts have been exported to neighbor countries in Latin America.

\section{Submédio São Francisco Valley}

It is situated in the tropical semi-arid region of Brazil, at $9^{\circ} \mathrm{S}$ laltitude, $40^{\circ} \mathrm{W}$ longitude and around $350 \mathrm{~m}$ altitude. The mean climate indicators are $500 \mathrm{~mm}$ rainfall, concentrated between December and March, $26^{\circ} \mathrm{C}$ temperature and $50 \%$ relative air humidity. It constitutes the main tropical grape producing region in Brazil, with around 8000 ha of vineyards spread over the states of Pernambuco and Bahia. Small holdings are linked to colonization projects and associated in cooperatives and medium and large growers operate on agribusiness scale. More than $90 \%$ of the planted vineyard areas are planted with table grapes mainly for exportation. Although the 'Italia' grape is still being grown on a large scale, especially by the small producers, it gives way to the seedless grapes, more appreciated on the international market. Among the seedless grapes, the cultivars 'Festival' ('Sugraone' or 'Superior') stand out as far as the cultivated area is concerned, as well as 'Thompson Seedless' and 'Crimson Seedless'; all of them have been planted recently and have boosted the Brazilian exports in the last years. The cultivation of $V$. vinifera varieties for wine production occupies an area of around 500 ha, mainly the red cultivars 'Syrah', 'Cabernet Sauvignon' and 'Ruby Cabernet' and among the white ones, 'Moscato Canelli' and 'Chemin Blanc'. Advanced research aiming at defining typical regional products, point out to the recommendation of other cultivars, which are adapted to the local conditions and appropriate to contribute to the 'typicality' 
of the regional products. The most used rootstocks are 'IAC 572', 'IAC 313', 'IAC 766', which have been developed especially for the tropical regions in Brazil, besides 'Harmony', 'SO4' and other less important ones. The great majority of the vineyards are trained in the arbor or pergola system. Recent initiatives have, since 2004, attempted to develop viticulture for grape juice production, using, for this purpose, new cultivars adapted to tropical conditions.

\section{Emerging Tropical Belts}

In several tropical regions in Brazil grape growing initiatives are emerging, especially in the northeast, in the states of Pernambuco, Bahia, Ceará, Maranhão and Piauí; in the mid-west, in the states of Goiás and Mato Grosso and in the Southeast, in the states of Espírito Santo and Minas Gerais, which are mainly destined to table grapes production. With respect to grapes for processing, the following projects stand out: a) a project with the objective to produce grapes for processing juice established in Nova Mutum in Mato Grosso state: 35 hectares have already been planted and 750,000 liters of natural, whole juice are produced per year; b) a project aiming at the production of grapes for table wines, established in Santa Helena de Goiás in the state of Goiás, where more than 50 ha and industrial facilities for processing 1 million liter wine/year have already been established. This project is planned to reach a total production output of 33 million liter wine/year; and c) two projects designed to produce grape juice in Santa Maria da Boa Vista, Pernambuco state, with more than 40 ha already planted.

\section{PERSPECTIVES FOR GRAPE GROWING IN BRAZIL}

The climatic diversity of Brazil's regions, which is mainly determined by variation of latitude, altitude and in the availability of water, due to the occurrence of dry periods, offers opportunities to obtain qualitatively different products throughout the year, in the different viticultural segments.

With regard to table grapes, the different producer regions ensure, complementing each other, permanent market supply, with quality grapes throughout the year. The cultivation of seedless grapes seems to be increasing in the following years mainly in tropical regions.

Concerning to grapes for processing, there are promising tropical regions with aptitude to the production of quality wines, in which the dry period coincides with the period of mild temperatures. At high altitudes, this feature triggers a maturation period which lasts long enough to obtain grapes of high quality for the production of fine wines. In regards to popular table wines and also regarding juice, the main attraction has been the possibility to produce grapes throughout the year, hence the feasibility of processing large volumes in a small industrial plant.

Taking into account the advantages of tropical viticulture and the technological advancements that have been achieved, the Brazilian viticulture should increase in the next years as much for fresh market as for processing.

\section{ACKNOWLEDGEMENTS}

The authors thank the Brazilian Financier for Studies and Projects - FINEP - for the financial support to research projects on tropical grapes for fresh market and processing, which produced much of the information presented in this paper.

\section{Literature Cited}

Tonietto, J. 2005. Experiências de desenvolvimento de indicações geográficas: vinhos da Indicação de Procedência Vale dos Vinhedos. p.141-162. In: Valorização de produtos com diferencial de qualidade e identidade: indicações geográficas e certificações para competitividade nos negócios. Sebrae, Brasília. 
